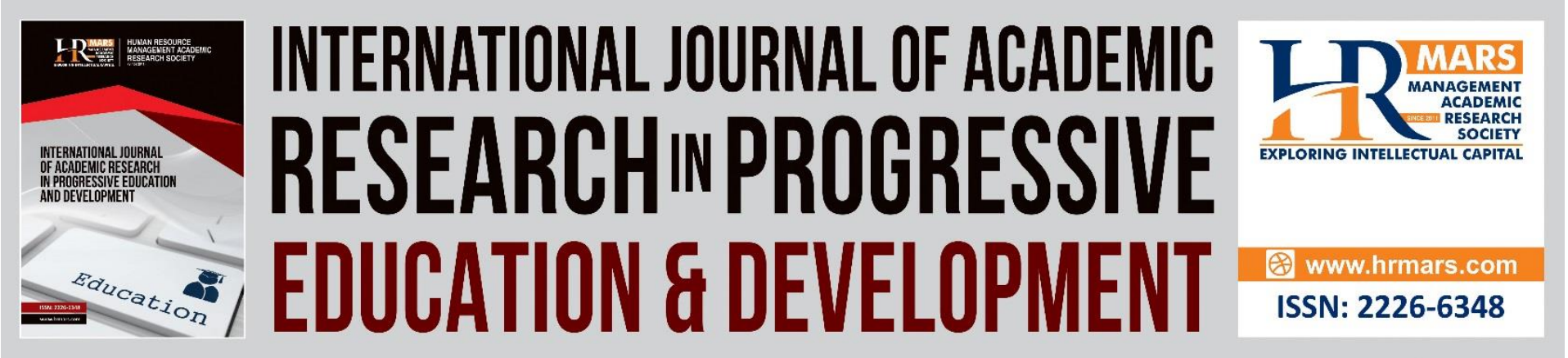

\title{
Effects of Traditional Lecture Method and Multi-Sensory Approach on ELT Learners at Graduate Level
}

Saima Maqbool, Shaik Abdul Malik Bin Mohamed Ismail, Saira Maqbool, Shahzad UI Hassan

To Link this Article: http://dx.doi.org/10.6007/IJARPED/v7-i4/5476

DOI: $10.6007 /$ IJARPED/v7-i4/5476

Received: 11 Sept 2018, Revised: 24 October 2018, Accepted: 04 Nov 2018

Published Online: 29 Nov 2018

In-Text Citation: (Maqbool, Ismail, Maqbool, \& Hassan, 2018)

To Cite this Article: Maqbool, S., Ismail, S. A. M. B. M., Maqbool, S., \& Hassan, S. U. (2018). Effects of Traditional Lecture Method and Multi-Sensory Approach on ELT Learners at Graduate Level. International Journal of Academic Research in Progressive Education and Development, 7(4), 488-505.

\section{Copyright: (C) 2018 The Author(s)}

Published by Human Resource Management Academic Research Society (www.hrmars.com)

This article is published under the Creative Commons Attribution (CC BY 4.0) license. Anyone may reproduce, distribute, translate and create derivative works of this article (for both commercial and non-commercial purposes), subject to full attribution to the original publication and authors. The full terms of this license may be seen at: http://creativecommons.org/licences/by/4.0/legalcode

\section{Vol. 7, No. 4, 2018, Pg. 488 - 505}

Full Terms \& Conditions of access and use can be found at http://hrmars.com/index.php/pages/detail/publication-ethics 


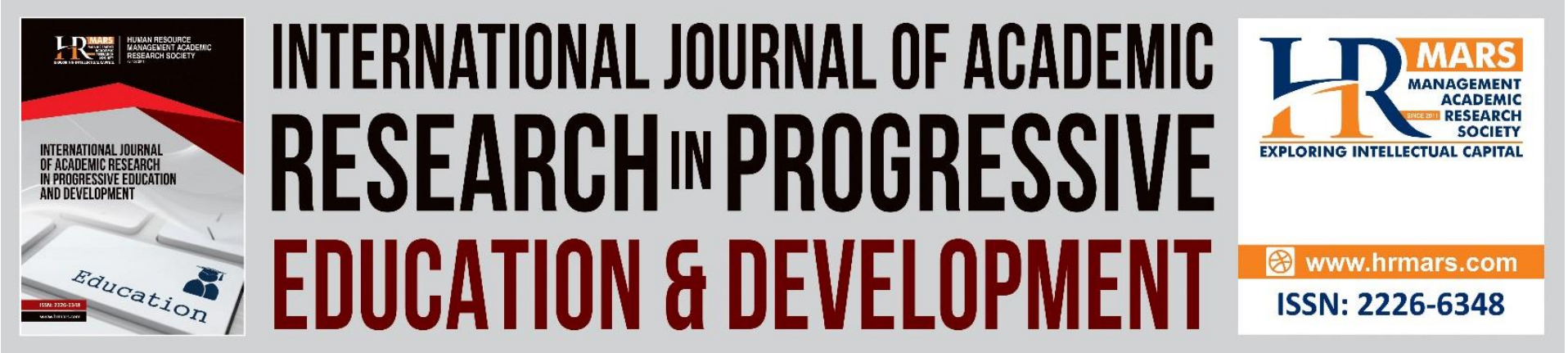

\title{
Effects of Traditional Lecture Method and Multi- Sensory Approach on ELT Learners at Graduate Level
}

\author{
Saima Mqbool \\ Assistant Professor, School of Educational Studies, Science University of Malaysia. \\ Email: saima@student.usm.my \\ Shaik Abdul Malik Bin Mohamed Ismail, PhD. \\ Associate Professor, Department of Educational Studies, Department TESOL, University of \\ Science Malaysia, Malaysia. \\ Email: samalik@usm.my \\ Saira Maqbool, PhD. \\ Assistant Professor, Department of English Language and Linguistics Alama Iqbal Open \\ University Islamabad, Pakistan. \\ Email: saira.maqbool@aiou.edu.pk.

\section{Shahzad UI Hassan} \\ Department of Political Science, The Islamia University of Bahawalpur. \\ Email: shahzad1122000@yahoo.com
}

\begin{abstract}
The current study investigates the traditional verbal lecture method and the multi-sensory approach toward ELT at degree level. It was an investigative method having four groups, two controlled groups and two experimental groups who attempted pre-test and post-test. The controlled groups were taught with traditional lecture method and the experimental groups were taught to multisensory approach. Sample of 200 was selected form two universities randomly VAK Learning Styles Self-Assessment Questionnaire by Chislett and Chapman 2005 was used to know the dominant learning style of the learners. Descriptive statistics were used to find out the ratio of different styles of learner and correlation was find out to know the significant improvement of learning between the pre-test and post-test of all four groups. Some practical recommendations were suggested to make ELT teaching learning process more efficient.

Keywords: ELT Learners, Traditional Verbal Lecture
\end{abstract}


DEVELOPMENT

Vol. 7, No. 4, 2018, E-ISSN: $2226-6348$ (c) 2018 HRMARS

\section{INTRODUCTION}

Almost 6912 different languages are spoken in the world Harrison (2008). No nation of the world can survive with a single language. Amongst all these languages English is the most important language in today's world because no nation can even dream of development without it. In Pakistan it is used as a second official language that is why it occupies the place of a compulsory subject in Pakistani educational system from pre-nursery to graduate level. The development of education depends upon this language. Learning English language is a compulsion for progress in every field of life in the modern world. We learn it at primary, secondary and at degree level through various teaching/learning approaches, methods and techniques.

Cook (2008) asks two fundamental questions regarding second language acquisition research: What are the procedures through which learners learn a second language? What role a teacher can play in utilizing these procedures?

In order to know about teaching/learning English language we first need to know about different kinds of learning styles. Do all the learners learn the same way or there exists an individual in every learner?

An American Linguist William Moulton prepared a report in 1961 for the Ninth International Congress of linguistics (Diller 1975). It proclaimed the following linguistic principles of language teaching and according to him language teaching methodology should be based upon these principles: Language is a set of habits. And language is speech, not writing.

Thus if language is not just writing, it is a habit and a complete body in itself, the question arises how to teach a language to the adults who want to learn it as a second or foreign language. According to Pica (2000) in the past English language had been taught keeping in mind different approaches/methods. Some of these are shown in the following figure.

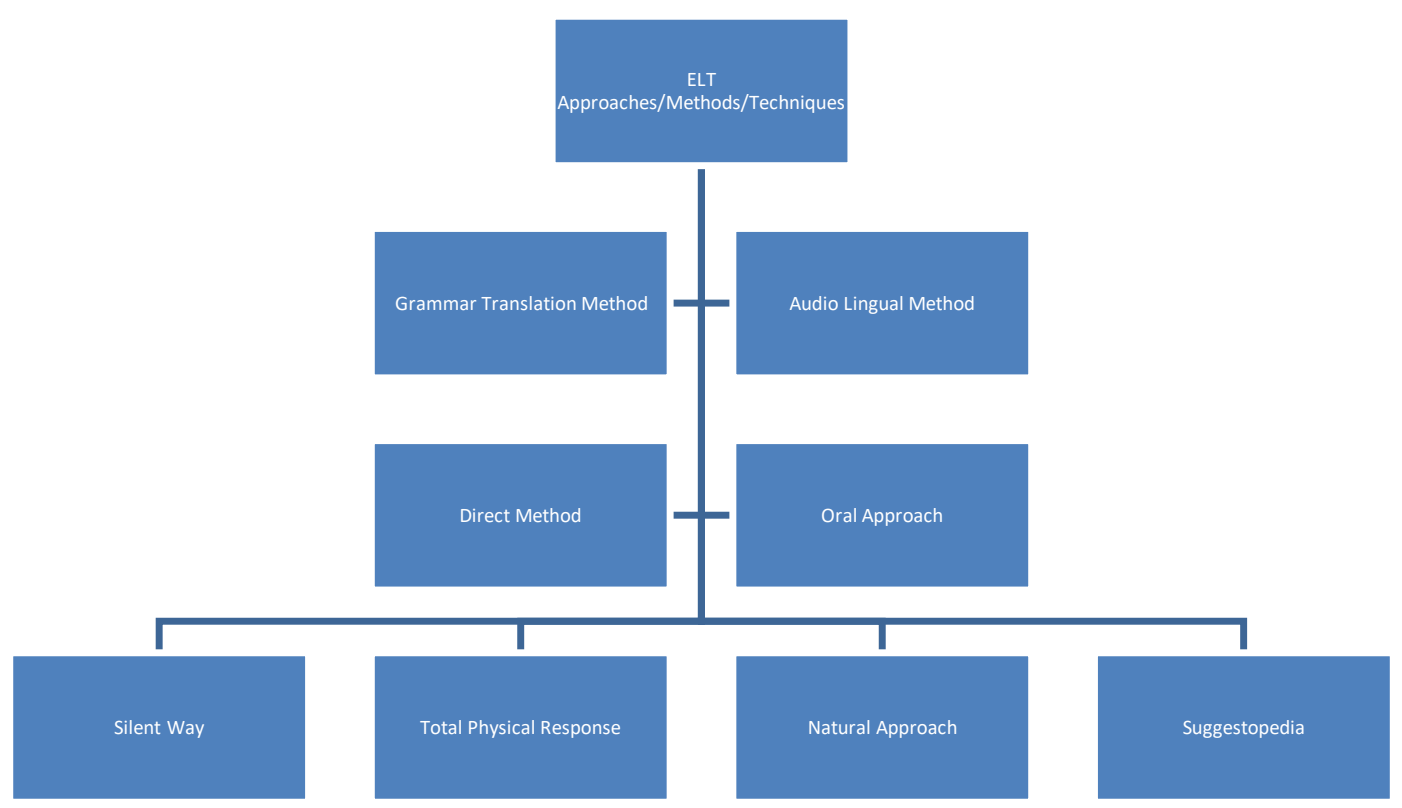

Figure 1.1 ESL Teaching Methods 
DEVELOPMENT

Vol. 7, No. 4, 2018, E-ISSN: $2226-6348$ ㄷ 2018 HRMARS

But the fact is no matter which approach, method or technique we adopt, the ultimate goal should be to stimulate, motivate and involve the learners in the process of learning. They should not just be passive spectators, they should be active participants.

Emmons and Anderson in their book Understanding Sensory Dysfunction: learning, development and sensory integration (2005) discussing the importance of sensory integration argue that information about the physical environment is given to us by senses. This information then flows into our brains. The brain then locates sorts and orders this sensory information in a well-organized and integrated manner. This information is later on used by the brain to form perceptions, behaviour and learning.

Sensory learning style simultaneously stimulates visual, auditory and stimulus systems of light, sound and motion by challenging these three sensory systems to work together and adapt multi-sensory learning. Simultaneous use of these senses for language learning improves speech, perception, understanding coordinated movements, social interaction and the ability to learn.

Lambert (2013) argues that an appreciation of the world derived from a full sensory experience is there in all the prominent researches of today. He further says that relatively recent research related to our learning in the fields of multiple intelligence and emotional intelligence suggests that diversity of sensory and intellectual stimuli is the key to increase our capacity for learning.

That is why if we want our teaching of English language to be long lasting and easily recallable we must keep in mind individual learning style differences. There are some particular ways through which we can keep all our students learn within the given time and within the given budget if we just know and accept that there exist different learners whose needs are different. We must, for example, accept that a learner whose dominant style of learning is visual will always be sitting confused and detached in an auditory class but it does not prove him to be a dumb learner.

Scholtes (2004) says that the old age was if the students have not learned, the teacher has not taught.' I don't see the truth or usefulness of that statement, I prefer to say' if the learner hasn't learned, the system isn't yet adequate" (Scholtes 2004, p .36)

Every learner has a distinct learning style e.g. auditory, visual or kinesthetic style. According to an analysis, 20 to 30 percent of the students in a class are auditory learners, which mean that they learn through reading or hearing. The rest are visual or kinesthetic or they learn through a combination of the above styles. At present, the most dominant style of teaching English language that exists in our educational system is auditory style, which means that our present language approach is satisfactory only for 20 to 30 percent of our students.

Although multi-sensory teaching approach has been accepted by the teachers since the earliest teaching theories were written (e.g. Fernald, 1943; Gillingham and Stillman, 1960; Montessori, 1921; Strauss and Lehtinen, 1947), it has seldom been well defined and appropriately used. In the multi-sensory approach for teaching English language learners are directed or inclined to use two or more than two senses at the same time to learn that helps learners to sustain interest as they use hearing, reading, seeing or experiencing at the same 
DEVELOPMENT

Vol. 7, No. 4, 2018, E-ISSN: $2226-6348$ ㄷ 2018 HRMARS

time or in the same lesson and it also helps in motivating the learners to learn by involving them in the learning activities as active participants.

A general concept is that multi-sensory techniques are only useful for children and not for adult learners but the new high-tack technology and recent findings from neuro-scientific studies have proved that even adult learners can have the same amount of benefit out of it. A learner's learning approach will always remain the same whether he is at primary level or at degree level. It was an old concept to use only one sense i.e. listening in teaching the adult learners but recent research shows that a learner learns better and retains information for a long time when he involves as many senses as possible in the process of learning.

\section{The Term Multi-Sensory}

Multi : More than one

Sensory : : Involving or derived from the senses

Multi-Sensory : Related with or involving several bodily senses

Multi-sensory approach towards learning combines many learning senses i.e. hearing, speaking, seeing, perceiving, touching etc. for teaching students. The term multi-sensory learning means any learning activity that includes the use of two or more than two sensory modalities simultaneously to take in or express information. It does not simply mean the use of multimedia as videotapes, audiotapes, or films. It rather means involving visual, auditory, tactile-kinesthetic components in the teaching of language structure with or without the use of these aids.

According to Westwood(2007) multi-sensory teaching simply means involving as many sensess as possible in the learning process in order to enhance awareness, attention and memory.

\section{Learning Styles}

If we want our students to gain success in learning English language, the only way for this is through their individual learning styles. Learning styles basically include auditory, visual, kinesthetic, and tactile components. Ryan and Deci, (2000) elaborating individual learning argue, It is important to recognize not only individual behaviours, but to explore and examine the whole of each person's inclinations toward learning.

Almodaimeegh, and Harrald (2009) referring to Suessmuth's work says that Suessmuth has identified three general types of personal learning style preferences

- Language learners who prefer to hear (auditory) language or see (visual) language. They are best at remembering information in word forms.

- Numerical learners who prefer to hear (auditory) or see (visual) numbers. They are best at numerical forms.

- AVK learners who prefer to learn through personal experiences and sensory stimuli. They need to manipulate material and be wholly involved . They may become distracted if not entirely involved. 


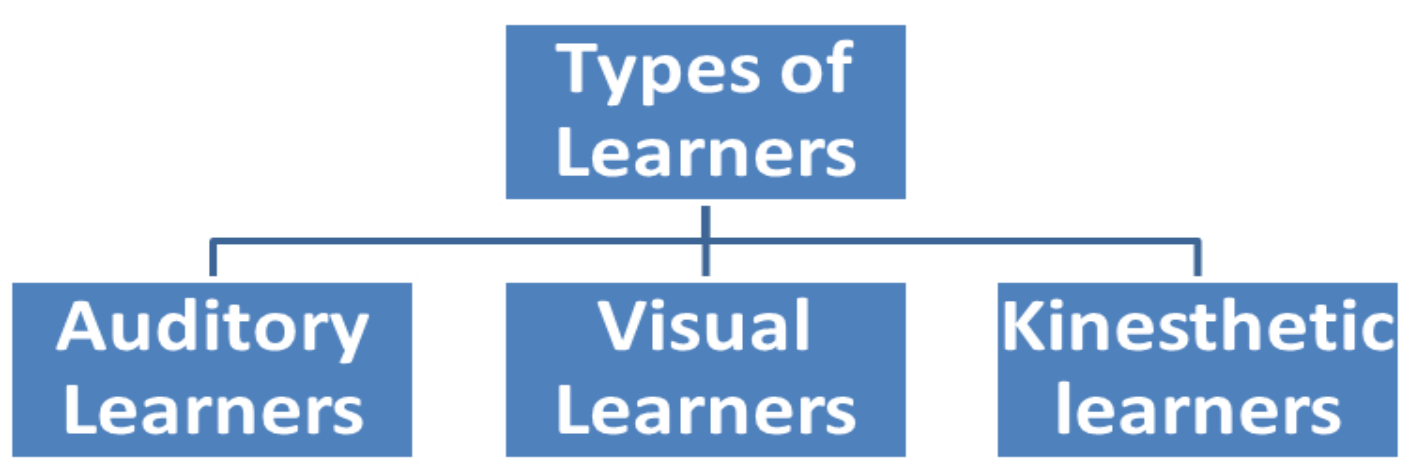

Figure 1.2 Types of Learners

\section{HISTORICAL BACKGROUND OF MULTISENSORY APPROACH TOWARDS TEACHING/LEARNING}

According to Neo (2007) multi-sensory teaching simply means involving as many senses as possible in the learning process in order to enhance awareness, attention and memory. MSLE (multi-sensory structural language education) has the most famous subject in the field of applied linguistics and education since 1990s (Lier, 2007). The proponents of MSLE believes in teaching language through techniques which involve almost all the senses i.e. seeing, listening, touching in the process of teaching. Although all the educational experts believe multi-sensory component to be the most important in teaching/learning process, this is the component which has been paid the least importance.

The term multi-sensory is used generically to refer to any learning activity that includes the use of two or more sensory modalities simultaneously to take in or express information. The term does not mean multimedia as playing videotapes or audiocassettes. It pertains to techniques for novice or poor readers that involve visual, auditory, tactile-kinesthetic, and/or articulatory-motor components in the teaching of language structure. For example, students learn alphabet letters by feeling, naming, and matching three-dimensional forms or tracing on rough surfaces; teachers and students model paragraph structure with graphic organizers; or students learn the identity of phonemes by feeling and seeing the position of the mouth, lips, and tongue.

A multi-sensory strategy is one that combines the use of two or more senses simultaneously. In a multi-sensory approach, a visual strategy is being used simultaneously with an auditory strategy and that for many learning tasks, kinesthetic and/or tactile strategies are also being used. For example, in working toward the sound-symbol association, if a student's visual reinforcement is looking at a letter, the auditory reinforcement is to listen to and hear the sound and identify it with its symbol. The kinesthetic reinforcement stems from the learner's feeling the articulator muscle movement associated with saying the phonemes.

In view of Westwood (2007) multi-sensory methods deliberately involve the learner in simultaneous use of visual, auditory and kinesthetic modalities (VAK). Multi-sensory 
instruction is one dimension of the practices and approaches useful with students who have problems with language learning, including reading and writing.

The idea that learning experienced through all senses is helpful in reinforcing memory has a very long history in language teaching. Educational psychologists of the late $19^{\text {th }}$ century promoted the theory that all senses, including the kinesthetic sense, are involved in learning. The second volume of James's (1890) The Principles of Psychology discussed Binet's theory that all perceptions, in particular those of sight and touch, involve movements of the eyes and limbs and that because such movement is essential in seeing an object, it must be equally essential in forming a visual image of the object. Consistent with this theory were observations that the loss of acquired reading ability because of impaired visual memory in adults with brain injury could be bypassed using a kinesthetic modality (tracing letters).

Thompson (1973) a neurologist, paper published on blindness proposed that there is a physiological failure of the brain to develop a clearly dominant language hemisphere to subsume reading, writing, and spelling. The lack of dominance, leads to an unusual persistence of symbolic reversals in dyslexic individuals. Advocating the use of all sensory pathways to reinforce weak memory patterns, Orton (1928) called for education methods based on simultaneous association of visual, auditory, and kinesthetic fields, for example, by having a person sound the visually presented word and establish consistent directionality by following the letters with the fingers during sound synthesis of syllables and words. He stressed the unity of the language system and its sensory motor connections and stated that listening, speaking, reading, and writing were interrelated functions of language that must be taught in random.

The methods for teaching of reading were developed by Montessori, Fernald and Keller, and Strauss and Lehtinen. A review of their methods reveals the multi-sensory nature of their instruction. Fernald also asserted the need for tactile experience in word learning and reported the learning rate to be much more rapid when finger tracing was used than when a stylus or pencil was used.

There had been a lot in favour of multi-sensory teaching, but at the same time some arguments were given against it as well because it was just a theoretical assumption and there were no empirical evidence in favour of it. For example Vicker, Reynolds and Cochran, (1987) believed that indeed whenever the multi-sensory techniques had been applied, the result had been positive but these positive results might have been due to other reasons rather than due to the application of multi-sensory techniques. They argued that for example these positive results might have been due augmented attention rather.

Goswami and Bryant (2007) tried to answer the objections laid down on multi-sensory teaching. She claimed the importance of kinesthetic learning for visually impaired students. Many studies have recognized the importance of multi-sensory techniques in teaching for example Luchow andShepherd (1981) Kaplan el.at (2006), Brett-Green el, at (2010) Thompson (2011), Rodger el, at (2012), Watling and Hauer( 2015). However, in spite of all this Bryant failed to justify multi-sensory approach because the popularity of this approach was only based on reports of success, not upon empirical evidences. 
Catts (1989) as well reached the same conclusion. He also argued that indeed these techniques had been used extensively in clinical studies and had been very much effective for dyslexic students but the specific contribution of the multi-sensory component to the overall success of those programs has not yet been thoroughly documented or explained through rigorous manipulation of instructional conditions and subsequent measurement of outcomes. Current reading research, however, does offer strong support for the content and overall approach of MSLE programs.

\section{Auditory Learners}

According to Colorosa, S. R., \& Makela (2014) auditory learners learn first through hearing and conversing.The spoken words are important.Students express themselves through discussion, conversation, and sounds. Robinson (2008) says about that Auditory learners find that they process information better if they hear it. According to Kelly (2010) an auditory learner would remember a word better by hearing it or saying it aloud. Such a learner learns better when he hear things. He may not be able to understand a lesson when he reads it but may fully understand it after listening to a class lecture. The best way to learn for these learners is to learn from verbal lectures or through class discussions or listening to others. The tone of voice, pitch, speed etc. are important to them. If a lesson is given to them in the written form, it may not be that much beneficial to them untill they don't read it aloud or use a tape recorder. Written information may have little meaning until it is heard. Thus learners who learns easily through lectures, verbal explanations, tapes and oral instruction are generally categorised as auditory learners.

\section{Visual Learners}

Duffelmeyer (2004) says that visual learners learn first by watching then reading and writing. The written words are important to them. Such students express themselves through charts, graphs, and pictures. According to Heiberg Engel, (2008) visual learners learn more from seeing information presented. They may retain more information if they see it in a chart or diagram.

According to Kelley et, al (2010) when a student remembers a word better if it is written down to him than simply hearing it, such a student is a visual learner. Such learners like to sit at the front of the class in order to be able to see the teacher and watch the lecture closely. Often, a visual learner will find that information "clicks in his mind" when it is explained with the aid of a chart or a picture.

Such learners often don't like to talk alot and sit quietly in the clasroom, however they like illustrations and diagrams etc. along with the verbal lessons. If we teach such learners with written instructions that will be very much beneficial to them. Acting out situations, watching a demonstration or presenting scenarios in videos also attracts their attention. In simple words we can say that if we have a student who seems to retain what he reads better than what he hears then that student is a perfect example of visual learners.

\section{Kinesthetic/Tactile Learners}

Scholete (2004) says about kinesthetic learners that they learn first by doing it- experience and activity, Objects, actions and feelings are important and students express themselves 
DEVELOPMENT

Vol. 7, No. 4, 2018, E-ISSN: $2226-6348$ (c) 2018 HRMARS

through movement, gestures, and touch. Whereas Engle (2008) says tactile/kinesthetic learners learn more by doing than by hearing or seeing.

According to Kelley(2010) tactical/kinesthetic learners would probably chose to write down a word in order to learn it . Tactile and Kinesthetic learners often don't at all understand what a teacher is trying to teach through a traditional lecture or even a worksheet based lesson. They learn when they are physically involved in the lesson to complete practice exercises. So we can conclude that tactile learners are physical learners.

\begin{tabular}{|l|l|}
\hline Learning Styles & Description \\
\hline Visual & seeing and reading \\
\hline Auditory & listening and speaking \\
\hline Kinesthetic & touching and doing \\
\hline
\end{tabular}

\section{The Multi-Sensory Approach towards Teaching/Learning}

Hoffman and Ralph (2013) argues that if we really want to engage our learners we should try taking a multi-sensory approach. Presentations that appeal to auditory, visual and kinesthetic modalities simultaneously connect more deeply and have a lasting impact.

Different learners have different approaches towards learning. Some learners are auditory learners or those with "verbal linguistic intelligence". Such learners are good at reading or hearing. The second category of learners is of visual learners or those with "visual/spatial intelligence". They have strong visual processing abilities and they prefer images for the learning of content. The third category is that of kinesthetic or tactile learners who are activity based learners because they learn through physical experiments and by trying things themselves. Multi-sensory teaching/learning approach is the combination of all three or the use of any two approaches of the above in the teaching/learning process. In this approach, a learner is expected to use or manipulate as many senses as possible for learning.

As the learning of any other skill, language acquisition also needs to be learned best by using all our senses, for as many senses are engaged in the process of learning that much the content has a lasting impact and improved recall pathways.

\section{RESEARCH QUESTIONS}

The research questions of the ongoing research are as following

- Does a learning group contain different categories/types of learners?

- Do all types of learners benefit equally from the traditional verbal lecture method?

- Do adult learners (degree level students) learn better when involving more than one sense simultaneously in the learning process?

- Do even passive learners (visual learners) benefit from multi-sensory teaching? Can teaching methodology be improved through multi-sensory teaching? 
DEVELOPMENT

Vol. 7, No. 4, 2018, E-ISSN: $2226-6348$ @ 2018 HRMARS

Hypothesis

H1: $\quad$ The English language learners who learned through multi-sensory techniques have shown significant improvement than those who were taught through traditional verbal lecture method.

$\mathrm{H} 2$ : $\quad$ The English language learners who learned through traditional verbal lecture method have shown significant progress than learners taught through multi-sensory method.

\section{Methodology}

In this experimental study, the pretest-posttest Equivalent group design was used (adopted from Watanable, Hare and Lonax, 1984).

This design may best be represented as
$\mathrm{RO} 1 \mathrm{XO2}$
$\mathrm{X}$ gain $=02-01$
$\mathrm{RO} 3 \mathrm{CO} 4$
$\mathrm{C}$ gain $=\mathrm{O} 4-\mathrm{O} 3$

\section{Where:}

$\mathrm{R}=$

$X=$

Random assignment of subjects to groups

$\mathrm{X}=$

Exposure of a group to an Experimental (treatment) condition

$\mathrm{C}=$
$\mathrm{O} 1,03=$

Exposure of a group to control condition

$\mathrm{O} 2, \mathrm{O} 4=$

Pre-tests

Post-tests

In this design pre-tests are administered before the application of the experimental and control treatments and the post-tests at the end of the treatment period.

This design was selected because it could minimize the threats to the experimental validity and the equivalence of the experimental and the control groups was provided by random assignment of subjects to control and experimental treatment.

\section{POPULAIONG AND SAMPLING}

Population is a group against which a researcher wants to obtain the result of his study. All the graduate level English language students of the public sector universities of K.Pk were taken as population for this study.

For the current study two universities i.e. the Abdul Wali Khan University Mardan and National University of Modern Languages Peshawar were selected out of sixteen public sector universities of the Khyber Pakhtun Khwa. These universities were selected by the process of simple random sampling using draw method technique. Out of twelve departments at AWKUM one i.e. Managment Sciences was selected randomly. In NUML since there are different languages taught, Department of English was selected intentionally to suit the need of current research. Again out of the four semester at graduate level in both universities, only the first semester students were selected as English is taught as a compulsory subject only in the first semester.

Then out of the two shifts at AWKUM, the morning shift was randomly assigned as the control group and the evening shift students as experimental group. To mantain balance in both groups, BA morning shift of NUML was assigned as experimental group and BA evening as a 
INTERNATIONAL JOURNAL OF ACADEMIC RESEARCH IN PROGRESSIVE EDUCATION AND

DEVELOPMENT

Vol. 7, No. 4, 2018, E-ISSN: 2226-6348 @ 2018 HRMARS

control group. All the four groups were taught by the researcher herself throughout the experiment.

\begin{tabular}{|l|l|l|l|l|}
\hline S.No & Groups & Institution & Learners & Number \\
\hline 1 & Control Group I & AWKUM & BBA Morning Shift & 50 Learners \\
\hline 2 & Control Group II & NUMUL & BA Evening Shift & 50 Learners \\
\hline 3 & Experimental Group I & AWKUM & BBA Evening Shift & 50 Learners \\
\hline 4 & Experimental Group II & NUMUL & BA Morning Shift & 50 Learners \\
\hline
\end{tabular}

\section{INSTRUMENTATION}

The following were used as instruments for this study

Learning style measurment the questionnaire used (VAK Learning Styles Self-Assessment Questionnaire by Chislett and Chapman 2005) consists of 30 objective type questions each question carrying 1 score which makes the total of 30 scores.

Ten multi-sensory lesson plans relating English language to be taught to the experimental groups only. Theses lessons were borrowed from the Kenneth Beare's collection of ESL lesson plans to be taught to only the experimental groups.

Two achievement tests in the subject of English were developed, one was used as pre-test and the other as post-test . For the preparation of the pre-test and the post-test, Kenneth Beare's test collection of ESL was utilized. The tests were selected in accordance with the lesson plans. The pre-test and post-test both were redesigned according to the situation and culture to find the language skills of the learners more appropriately before and after the lesson plans.

Four tests from the test collection of Kenneth Beare were taken named as

Test 1: Comparative and Superlative Forms Quiz

Test 2: Parts of Speech Quiz

Test 3: Countable and Uncountable-Noun quantifiers

Test 4: Review quiz

DATA ANALYSIS

Table 1: Percentages of Auditory, Visual, and Kinesthetic and Multiple Style Learners of All Groups

\begin{tabular}{lcccc}
\multicolumn{1}{c}{ Groups } & $\begin{array}{c}\text { Auditory } \\
\text { Learners }\end{array}$ & $\begin{array}{c}\text { Visual } \\
\text { Learners }\end{array}$ & $\begin{array}{c}\text { Kinesthetic } \\
\text { Learners }\end{array}$ & $\begin{array}{c}\text { Multiple } \\
\text { Style } \\
\text { Learners }\end{array}$ \\
\hline Control Group I & 13 & 11 & 23 & 3 \\
Experimental Group I & 11 & 13 & 25 & 1 \\
Experimental Group II & 14 & 12 & 20 & 3 \\
Control Group II & 12 & 14 & 19 & 5 \\
PERCENTAGE & $25 \%$ & $25 \%$ & $43.5 \%$ & $6 \%$ \\
\hline
\end{tabular}


DEVELOPMENT

Vol. 7, No. 4, 2018, E-ISSN: 2226-6348 @ 2018 HRMARS

Table 1 represents the sum total of all the auditory, visual, kinesthetic and multiple style learners of our sample. The number of auditory students in the Control Group-I is 13, in Experimental Group I is 11, in the Experimental Group II is 14 and in the Control Group II is 12. After summing up all these, we got 50 auditory learners, which are $25 \%$ of our sample. The number of visual students in Controlled Group I is 11, in the Experimental Group I is 13, in the experimental Group II is12 and in the Controlled Group II is 14. By summing up all these, we got 50 Visual learners, which is equal to $25 \%$ of our sample. The number of kinesthetic students in the Control Group I is 23, in the Experimental Group I is 25, in the Experimental Group II is 20 and in the Control Group II is 19. By summing up all these, we got the total number of kinesthetic learners in our sample which is 87 that counts up to $43.5 \%$ of our sample. The total number of multi style learners in the Control Group I is 3, in the Experimental Group I is 1, in the Experimental Group II is 3 and in the Control Group II is 5. By summing up all these, we got the total number of multi style learners in our sample that is 12 which makes up $6 \%$ of our sample.

\section{Graphic No 1: Auditory Visual, Kinesthetic and Multi Style Learners of All the Four Groups}

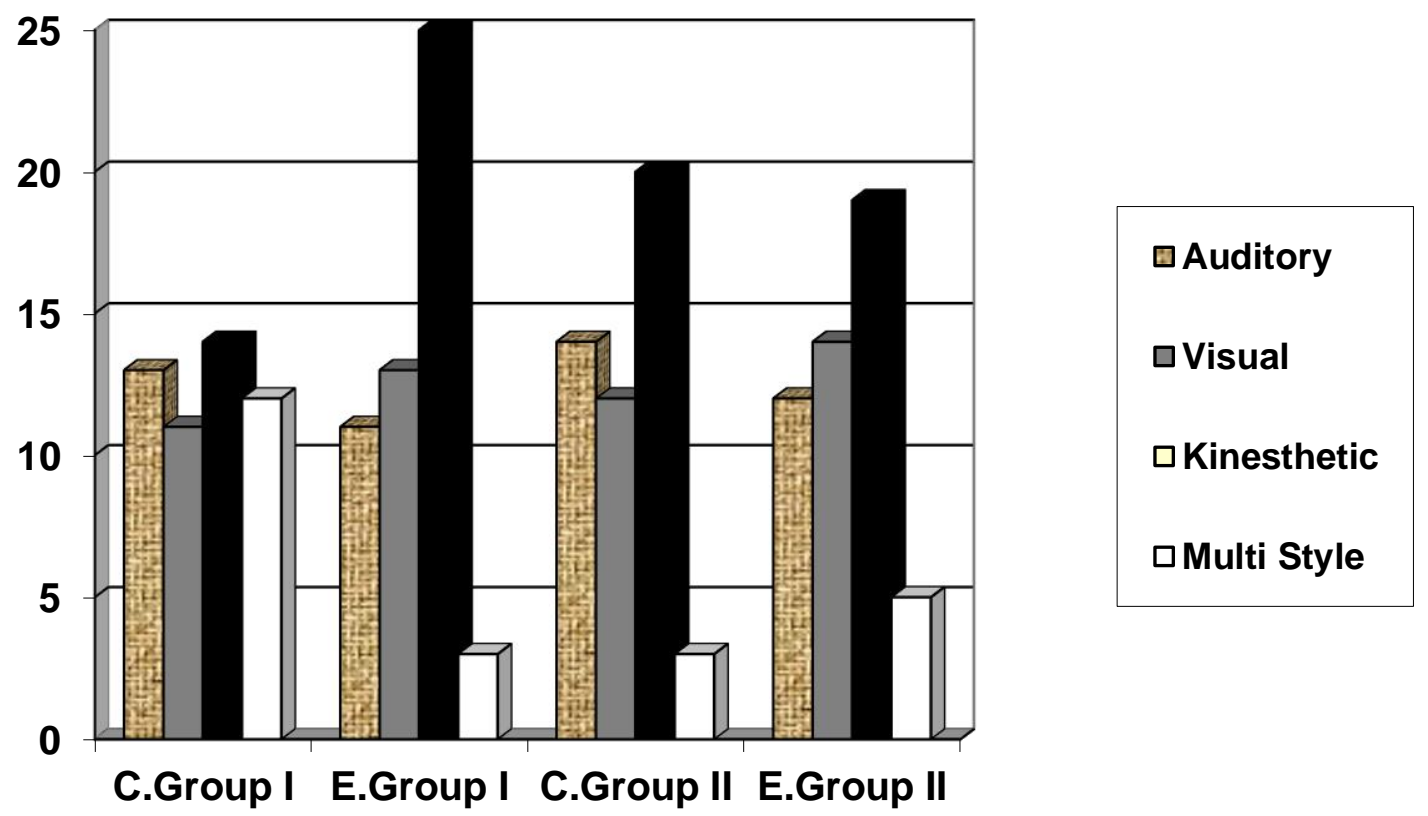

\section{Graphic Representation (2) of the Ratio of Different Styles of Learners}

1 Auditory learner $25 \%$

2 Visual learners $25 \%$

3 kinesthetic learners $44 \%$

4 Multiple style learners $6 \%$ 
INTERNATIONAL JOURNAL OF ACADEMIC RESEARCH IN PROGRESSIVE EDUCATION AND DEVELOPMENT

Vol. 7, No. 4, 2018, E-ISSN: $2226-6348$ @ 2018 HRMARS

Table 2: Sum Total of the Average \% Differences Between Both the Control and Experimental Groups

\begin{tabular}{llll} 
& Control & Experimental & Difference \\
\hline Group I & $64 \%$ & $87 \%$ & $23 \%$ \\
Group II & $52 \%$ & $66 \%$ & $14 \%$ \\
& & & \\
\hline
\end{tabular}

Sum Total of the Average \% Differences Between Both the Control and Experimental Groups Table 4.16 shows the average \% marks difference of Control group I (64\%) and Control group II (52\%) and Experimental Group I (87\%) and Experimental Group II (66\%). It shows the progress rate of the experimental group I (23\%) and Experimental group II (14\%) is more than the control groups.

Graph No 2: Comparison between the Progress of both Experimental and Control Groups

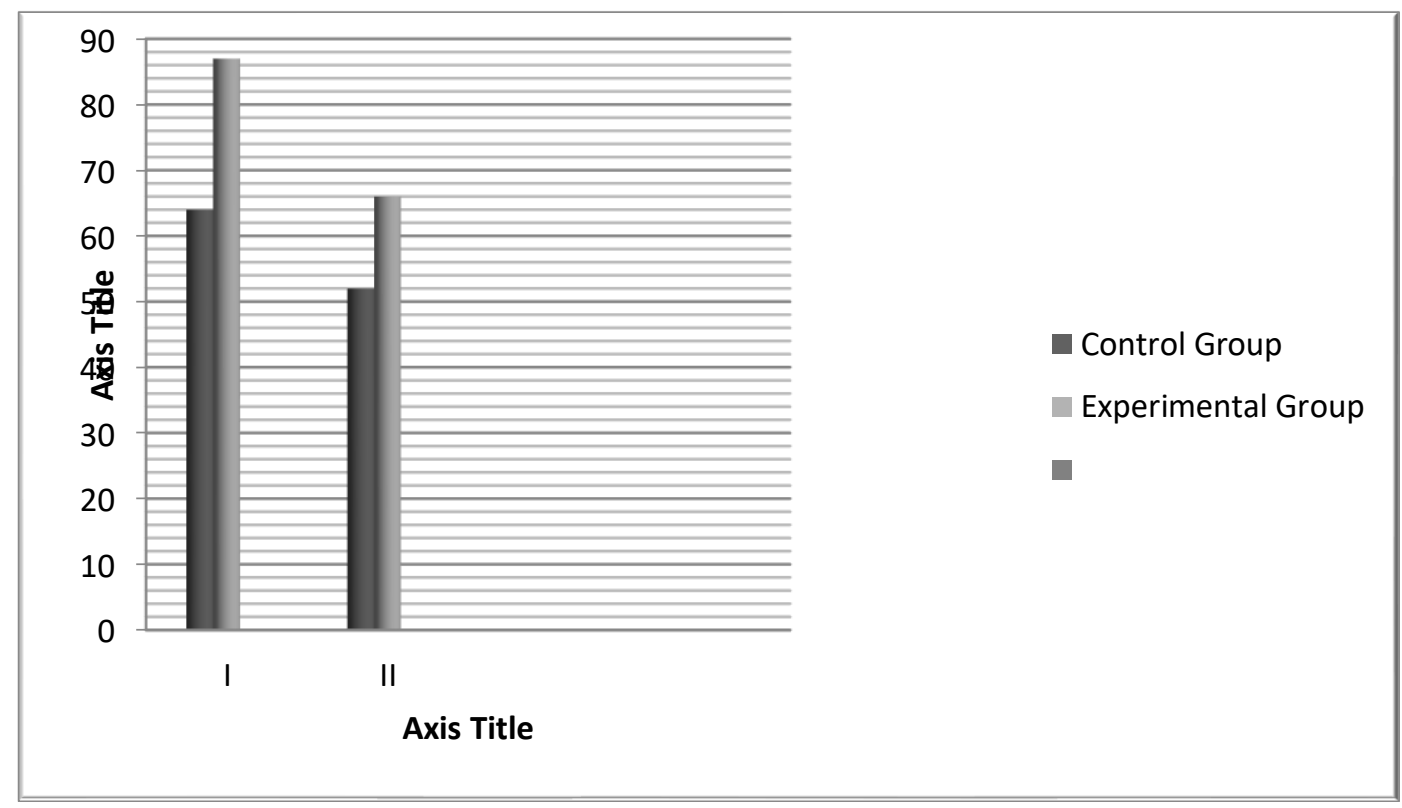


INTERNATIONAL JOURNAL OF ACADEMIC RESEARCH IN PROGRESSIVE EDUCATION AND

DEVELOPMENT

Vol. 7, No. 4, 2018, E-ISSN: 2226-6348 @ 2018 HRMARS

Table No 3: Correlation of Control group pre and posttest and Experimental group pre and posttest.

\begin{tabular}{|c|c|c|c|c|c|c|c|c|c|}
\hline & & 1 & 2 & 3 & 4 & 5 & 6 & 7 & 8 \\
\hline $\mathrm{C}$ & Pearson & 1 & & & & & & & \\
\hline \multirow[t]{2}{*}{ I.Pre.test } & Correlation & & & & & & & & \\
\hline & $\begin{array}{l}\text { Sig. (2- } \\
\text { tailed) }\end{array}$ & & & & & & & & \\
\hline C & Pearson & $.457^{* *}$ & 1 & & & & & & \\
\hline \multirow[t]{2}{*}{ I.Post.test } & Correlation & & & & & & & & \\
\hline & $\begin{array}{l}\text { Sig. (2- } \\
\text { tailed) }\end{array}$ & 0.001 & & & & & & & \\
\hline EI. & Pearson & - & 0.088 & 1 & & & & & \\
\hline \multirow[t]{2}{*}{ Pre.test } & Correlation & 0.136 & & & & & & & \\
\hline & $\begin{array}{l}\text { Sig. (2- } \\
\text { tailed) }\end{array}$ & 0.345 & 0.542 & & & & & & \\
\hline E I. Post. & Pearson & - & 0.107 & $.800^{* *}$ & 1 & & & & \\
\hline \multirow{2}{*}{ Test } & Correlation & 0.094 & & & & & & & \\
\hline & $\begin{array}{l}\text { Sig. }(2- \\
\text { tailed })\end{array}$ & 0.517 & 0.460 & 0.000 & & & & & \\
\hline E II. & Pearson & 0.190 & -0.079 & -0.147 & -0.067 & 1 & & & \\
\hline \multirow{2}{*}{ Pre.test } & Correlation & & & & & & & & \\
\hline & $\begin{array}{l}\text { Sig. (2- } \\
\text { tailed) }\end{array}$ & 0.186 & 0.585 & 0.307 & 0.645 & & & & \\
\hline \multirow{3}{*}{$\begin{array}{l}\text { E II. Post. } \\
\text { Test }\end{array}$} & Pearson & 0.160 & -0.096 & -0.268 & -0.266 & $.808^{* *}$ & 1 & & \\
\hline & Correlation & & & & & & & & \\
\hline & $\begin{array}{l}\text { Sig. (2- } \\
\text { tailed) }\end{array}$ & 0.268 & 0.508 & 0.060 & 0.062 & 0.000 & & & \\
\hline CII & Pearson & 0.026 & -0.027 & 0.072 & -0.088 & -0.021 & 0.263 & 1 & \\
\hline \multirow[t]{2}{*}{ Pre.test } & Correlation & & & & & & & & \\
\hline & $\begin{array}{l}\text { Sig. (2- } \\
\text { tailed) }\end{array}$ & 0.860 & 0.852 & 0.620 & 0.544 & 0.887 & 0.065 & & \\
\hline C II & Pearson & - & 0.109 & -0.239 & -0.180 & -0.024 & 0.098 & $.442^{* *}$ & 1 \\
\hline \multirow[t]{2}{*}{ Post.test } & Correlation & 0.040 & & & & & & & \\
\hline & $\begin{array}{l}\text { Sig. }(2- \\
\text { tailed) }\end{array}$ & 0.781 & 0.451 & 0.095 & 0.212 & 0.870 & 0.499 & 0.001 & \\
\hline
\end{tabular}

**. Correlation is significant at the 0.01 level (2-tailed).

The table shows the level of correlation between Control group I pretest and post-test having low correlation of 0.088 whereas the correlation of Experimental group I pre-test and post-test is $.800^{* *}$ which shows high correlation resulting in high level of significance. It presents the score of Experimental group II the correlation between Pre-test and post-test which is $.808^{* *}$ meaning it is carrying high significance as compared to the Controlled group II pre-test and pot-test correlation which is $.442 * *$ with moderate level of significance. 


\section{CONCLUSION}

The findings of the study led to the following conclusions that data obtained through the questionnaire led to the conclusions that every individual has a different learning style, almost $24 \%$ of the total students in a class are visual learners, $24 \%$ auditory, $40 \%$ are kinesthetic learners and almost $4 \%$ are of mixed learning ability in both BBA morning and evening shift classes of the Abdul Wali Khan University Mardan. which proved that almost every learner has his/her own learning style but every individual uses many types of learning styles at the same time to learn English language in order to fertile their various part of the brain, which makes the data easy to learn and understand and accessible for future recall.

The experimental and control groups both were equivalent at the time of starting the experiment as the pre-test results show. But the post-test results show that the experimental groups have shown significant progress than the control groups.

Teaching of English language through the multi-sensory approach plays a positive role in the academic achievement of the students learning English at the degree level. The percentage of the learning of experimental group was $22 \%$ better than that of the controlled group, which concluded that the learning that has made through multi-sensory was more effective than the learning made through the traditional approach.

\section{RECOMMENDATIONS}

In the light the research conducted, the following recommendations can be made regarding the ELT at graduate level in Pakistan:

Teachers of English language should use multi-sensory approach in the classroom so that in the process of learning as many senses would be used by the learner as possible, which will make the learning more effective and easily recallable, and the learners will take deep interest in learning. As Woo el at (2018) says video, audio, computer and multimedia communication should be added so that the learning should be more effective. Students should be involved in the learning process as active participants and the material to be thought should be made interesting by presenting it through audio visual aids. Without the learner's full involvement in the teaching/learning process, all teaching is futile' thus the most important learning principle. Lopez (2013) regards learning to be a self-activity.

The teachers should know that every individual has his/her own learning style and should keep it in mind while he/she enters a classroom and should not treat everyone with the same stick. Managal (2009) argues that multi-sensory approach of teaching/learning works satisfactorily in meeting the intellectual and psychological needs of the individual learners.

As we are living in a developing country, it is not possible to use highly advance technology and $A V$ aids in order to stimulate the senses of the learners but there are some cost-efficient ways of simulating the senses of the students to make them learn and understand English as much as possible. One of these cost-efficient ways is designing such lessons which will meet the auditory, visual and kinesthetic needs of the learners.

Moreover, the curriculum development body should keep in mind while making the curriculum that it is not too static. It should provide the flexibility of material and method. As it is not possible for every institution to make the necessary AVA available to the learners that is very heavy in cost but the curriculum should also allow such helpful aids which are cost effective and easily available. Baines (2008) 
Stimulate learning by engaging students on multiple levels. Learning takes place when even a single sense is involved in the process but it is even more effective when more than one sense of the learners is being used in the process. As many senses are involved that much effective, the learning will be. Have lots of practice in having their hands, eyes, ears, and voices working together for the conscious organization and retention of their learning. It is the responsibility of a teacher to make a learner practice all his/her senses in order to be good at learning English language that is he/she shouldn't just know how to read he/she should know how to read, write, understand and pronounce well English language. In order to achieve this task a teacher should make the learner practice English language using his/her eyes, ears and voices working together.

Besides teachers should provide experience rather than just telling the learners what to learns they should be more innovative with their teaching style (Tukimin, Yusoff, Baharudin, \& Hussain, 2018). The real sole of teaching is in giving the experience of actually doing or performing the task that the learners are expected to learn. According to Isaak in order to improve the oral and witten skills of student activities such as drawings, role-play games, pantomimes as well as songs can play importatnrole. The knowledge of information that they get through experiencing is far easier to understand and recall than that of taken through just using a single sense that mostly is sense of hearing.

Atienza argues that to become effective in teaching the teacher should be able to tailor his teaching methods to the nature and needs of the learners. Teacher should not teach through his dominant style of learning. The basic tragedy with the current teaching learning situation is that out teachers teach keeping in view their own style of learning. They do not consider that they should keep in mind the learners and their dominant style of learning that is whether they are auditory, visual or kinesthetic learners.

Moulton (1961) regards language is a set of habits. If it is said about language that it is a set of habits than how can a habit be thought to a learner just by involving only one sense in order to get the right amount of learning. In order to have good grip over language a learner must involve all his/her senses into its while learning. Learners should use as many senses in the process of learning as possible to make the language absorbed in their lives, as it should become their habit

\section{References}

Almodaimeegh, H., \& Harrald, J. (2009, June). Predicting debugging successs: an investigation of the relationship between learning styles, personality traits, and computer program debugging. In EdMedia+ Innovate Learning (pp. 2702-2710). Association for the Advancement of Computing in Education (AACE).

Baines, L. (2008). A teacher's guide to multisensory learning: Improving literacy by engaging the senses. ASCD.

Brett-Green, B. A., Miller, L. J., Schoen, S. A., \& Nielsen, D. M. (2010). An exploratory eventrelated potential study of multisensory integration in sensory over-responsive children. Brain research, 1321, 67-77.

Catts, H. W. (1989). Defining dyslexia as a developmental language disorder. Annals of Dyslexia, 39(1), 50. 
DEVELOPMENT

Vol. 7, No. 4, 2018, E-ISSN: 2226-6348 @ 2018 HRMARS

Colorosa, S. R., \& Makela, C. J. (2014). Integrative Literature Review: Styles of Learning for Autism Spectrum Disorders and Human Resource Development: Informing Performance Management. International Journal of Business and Social Science, 5(13).

Cook, V. (2008). Multi-competence: Black hole or wormhole for second language acquisition research. Understanding second language process, 25, 16-26.

Diller, K. C. (1975). Some new trends for applied linguistics and foreign language teaching in the United States. TESOL Quarterly, 65-73.

Duffelmeyer, B. B. (2004). Visualizing respect: Visual media literacy and students' understanding of globalization and technology issues. Journal of Visual Literacy, 24(2), 165184.

Emmons, P., \& Anderson, L. (2005). Understanding sensory dysfunction: learning, development and sensory dysfunction in autism spectrum disorders, $A D H D$, learning disabilities and bipolar disorder. Jessica Kingsley Publishers.

Goswami, U., \& Bryant, P. (2007). Children's cognitive development and learning. Harrison, K. D. (2008). When languages die: The extinction of the world's languages and the erosion of human knowledge. Oxford University Press.

Heiberg Engel, P. J. (2008). Tacit knowledge and visual expertise in medical diagnostic reasoning: implications for medical education. Medical Teacher, 30(7), e184-e188.

Hoffman, P., \& Ralph, M. A. L. (2013). Shapes, scents and sounds: quantifying the full multisensory basis of conceptual knowledge. Neuropsychologia, 51(1), 14-25.

Tukimin, R., Yusoff, N. M. R. N., Baharudin, H., \& Hussain, F. (2018). Innovative Arabic Language Teacher: A Dream or A Hope. International Journal of Academic Research in Progressive Education and Development, 7(4), 158-165.

Isaak, R. (2014). Creative writing activities and TPR plus: An implementation of foreign language development project to students with dyslexia. Multilingual Academic Journal of Education and Social Sciences, 2(1).

Kaplan, H., Clopton, M., Kaplan, M., Messbauer, L., \& McPherson, K. (2006). Snoezelen multi-sensory environments: Task engagement and generalization. Research in developmental disabilities, 27(4), 443-455.

Kelley, J. G., Lesaux, N. K., Kieffer, M. J., \& Faller, S. E. (2010). Effective academic vocabulary instruction in the urban middle school. The Reading Teacher, 64(1), 5-14.

Lambert, J. (2013). Digital storytelling: Capturing lives, creating community. Routledge. Lier, L. V. (2007). Action-based teaching, autonomy and identity. International Journal of Innovation in Language Learning and Teaching, 1(1), 46-65.

Lopez, N. S. (2013). Implementation of the National Competency-Based Teacher Standards in the UV-College of Teacher Education. University of the Visayas-Journal of Research, 7(1), 153-170.

Luchow, J. P., \& Shepherd

Luchow, J. P., \& Shepherd, M. J. (1981). Effects of multisensory training in perceptual learning. Learning Disability Quarterly, 4(1), 38-43.

Mangal, S. K. (2009). Essentials of educational technology. PHI Learning Pvt. Ltd. Moulton, W. G. (1961). Applied linguistics in the classroom. Publications of the Modern Language Association of America, 1-6.

Neo, M. (2007). Learning with multimedia: Engaging students in constructivist learning. International Journal of Instructional Media, 34(2), 149-159. 
Orton, S. T. (1928). Specific reading disability-strephosymbolia. Journal of the American Medical Association, 90(14), 1095-1099.

Pica, T. (2000). Tradition and transition in English language teaching methodology. System, 28(1), 1-18.

Robinson, R., Molenda, M., \& Rezabek, L. (2008). Facilitating learning. Educational technology: A definition with commentary, 15-48.

Rodger, S., Ashburner, J., \& Hinder, E. (2012). Sensory interventions for children: Where does our profession stand?. Australian occupational therapy journal, 59(5), 337-338.

Ryan, R. M., \& Deci, E. L. (2000). Self-determination theory and the facilitation of intrinsic motivation, social development, and well-being. American psychologist, 55(1), 68.

Thompson, C. J. (2011). Multi-Sensory Intervention Observational Research. International Journal of Special Education, 26(1), 202-214.

Thompson, L. J. (1973). Learning disabilities: an overview. American Journal of Psychiatry, 130(4), 393-399.

Vickery, K. S., Reynolds, V. A., \& Cochran, S. W. (1987). Multisensory teaching approach for reading, spelling, and handwriting, Orton-Gillingham based curriculum, in a public school setting. Annals of Dyslexia, 37(1), 189-200.

Watling, R., \& Hauer, S. (2015). Effectiveness of Ayres Sensory Integration ${ }^{\circledR}$ and sensorybased interventions for people with autism spectrum disorder: A systematic review.

American Journal of Occupational Therapy, 69(5), 6905180030p1-6905180030p12.

Westwood, P. (2007). Commonsense methods for children with special educational needs. Routledge.

Woo, P., Shahril, A. M., Azmi, E. \& Rosli, H. (2018). Interactive Learning Online: A Case Study of Front Office Teaching and Learning in Higher Learning Institution in Malaysia.

International Journal of Academic Research in Business and Social Sciences, 8(15), 201-211 